\title{
Perceived Value of Health Insurance and Enrollment Decision among Low-Income Population
}

Jayoung Han, PhD

School of Pharmacy and Health Sciences Fairleigh Dickinson University

\begin{abstract}
The individual mandate is one of the key features of the Affordable Care Act (ACA) and has contributed to a substantial decrease in the overall uninsured rate. We examined the relationship between the individual's insurance status and his/her attitude towards risk and uncertainty among the nonelderly adults, without employer-sponsored insurance (ESI) sources and who are most likely to benefit from the ACA. A descriptive, cross-sectional study was conducted using the 2014 full-year consolidated data file from the Household Component of the Medical Expenditure Panel Survey-Household Component (MEPS-HC). This study included 4,848 individuals, aged 18-64 years, with incomes between 138-400 \% of the Federal Poverty Level (FPL), and without access to public coverage or ESI. We examined the factors associated with the likelihood of being uninsured using a logit model. We found that the proportion of the uninsured among the low-income nonelderly adults without ESI (31.1\%) was much higher than the one among the nonelderly adults (14.3\%). The uninsured adults were likely to have lower demand for insurance and perceived value of insurance and were less likely to visit a doctor or to fill prescription drugs. More rigorous outreach efforts focusing on increasing perceived value of health insurance could contribute to an increased insurance coverage among low-income populations.
\end{abstract}

Keywords: Affordable Care Act, health insurance, enrollment, low income, perceived value

\section{Introduction}

The Affordable Care Act (ACA) requires people to have a health insurance. Under the law, people who do not have health insurance-either through public programs or employersmust purchase private health insurance in the individual market or otherwise pay a penalty. As of 2016, the penalty for not having health insurance was greater of the following two amounts: either $\$ 695$ per adult and $\$ 347.5$ per child, or $2.5 \%$ of household income above the tax return filing threshold. ${ }^{1}$ Furthermore, the ACA has established a new individual market "marketplace" and offered income-based financial assistance in order to provide an affordable coverage to low- and middleincome populations. While the overall uninsured rate has continuously declined since the ACA was put into effect, ${ }^{2}$ there are people who still choose to remain uninsured.

The prospect theory has been used to explain an individual's decision-making in a variety of insurance contexts including property insurance, ${ }^{3}$ annuities, ${ }^{4}$ and health insurance. ${ }^{5-7}$ This theory suggests that people set their own reference points and use them to define expected gains and losses. ${ }^{8-9}$ We framed the reference point of insurance enrollment decision as individual's initial wealth, as was done by Eckles and Wise (2011). ${ }^{6}$ If people stayed healthy and there are no health care expenditures, the premiums paid will be felt as "losses" with certainty. People would not feel the "gains" until the premiums pay off their

Corresponding author: Jayoung Han, PhD Assistant Professor of Pharmacy Practice School of Pharmacy and Health Sciences Fairleigh Dickinson University 230 Park Avenue, Florham Park, NJ 07932 USA Email: jayoung@fdu.edu; Phone: 973-443-8419 health care expenses, which may or may not happen. The problem is that people weigh the losses more than gains and people value outcomes with certainty more than outcomes with uncertainty. ${ }^{8}$ Consequently, people would select to buy health insurance if they are certain that their health care expenses will exceed the premiums they have paid, while insurers can hardly know about the individual's certain losses. Given such an information asymmetry between insurers and beneficiaries, adverse selection can happen. ${ }^{10}$

To mitigate adverse selection in the individual insurance market, the ACA attempts to shift the reference point from initial wealth (i.e., uninsured status) to initial wealth minus premiums (i.e., insured status) by requiring people to have health insurance; in other words, the ACA attempts to switch the default option from being uninsured to being insured. With this new reference point, people will not view premiums as losses the way they did with the previous reference point of initial wealth. With an absence of certain losses, being uninsured is obviously not an attractive option any longer to people at lower risk of having health problems and as a result adverse selection can be reduced. The Massachusetts' health reform has provided evidence on the effect of individual mandate on the reduction in adverse selection. ${ }^{11}$

After the implementation of ACA, a study has found that the hospitalization experience and chronic health problems are associated with more people signing up for insurance among the long-term uninsured residents in South Carolina, ${ }^{12}$ but this study population did not exclude the ones eligible for Medicaid and also did not explain the underlying mechanism for this association. We focused our analyses on the populations in poverty, who are neither eligible for public coverage nor for ESI coverage, because they were the most susceptible to adverse 
selection and thus, would be the most benefited from marketplace subsidies. We empirically assessed how these individuals responded to the ACA, using the prospect theory framework. We then described the individuals' attitude towards risk and uncertainty with respect to their insurance status and evaluated if the individuals felt that they earned "losses" or "gains" by buying the health insurance. Previous studies have shown that the attitude towards risk and uncertainty was positively associated with private health insurance coverage among young adults aged 18-24, and also with take-up of employer-sponsored insurance (ESI). ${ }^{13-14}$ We also examined the factors that are associated with the likelihood of being uninsured with an emphasis on the attitude towards risk and uncertainty, using a logit model.

\section{Methods}

We used a descriptive, cross-sectional study design and analyzed the data from the 2014 full-year consolidated data file from the Medical Expenditure Panel Survey-Household Component (MEPS-HC) released in September 2016. The Medical Expenditure Panel Survey (MEPS) is a nationally representative panel survey sponsored by the Agency for Healthcare Research and Quality (AHRQ). The data for 2014 were collected from MEPS Panels, in Rounds 1, 2, and 3 for Panel 19 and Rounds 3, 4, and 5 for Panel 18.

Our study population included nonelderly adults with incomes between $138-400 \%$ of federal poverty level (FPL) and who were without ESI coverage. Among these nonelderly adults (aged 1864 years as of December 31, 2014), we identified individuals who were eligible for marketplace financial assistance (incomes $138-400 \%$ of $\mathrm{FPL}$ ) using a poverty level summary variable (POVLEV14) and then excluded those individuals who were offered continuous health insurance, throughout the year, by their employers. These selected people were eligible for marketplace financial assistance regardless of their residing states adopting Medicaid expansion.

We used 2014 summary variables to represent the insurance status (UNINS14, individuals who were insured throughout a year equal to 1 and others equal to 0 ), age (AGE14X), household income (FAMINC14), and census region (REGION14). We created several binary variables to represent the employment status (individuals who were continuously employed for 2014 equal to 1 and others equal to 0 ), employers offering health insurance (individuals who were continuously provided health insurance from their employers for 2014 equal to 1 and other equal to 0), Hispanic ethnicity (individuals with Hispanic ethnicity equal to 1 and others equal to 0 ), and education (individuals who received education less than high school or received high school diploma equal to 1 and others equal to 0 ). We also formulated binary variables to represent office-based provider's visits (individuals without provider visit equal to 1 and others equal to 0 ) and prescription refills (individuals without refills equal to 1 and others equal to 0 ). The estimates were weighted to represent U.S. population using the personlevel composite weight variable of Panels 18 and 19 (PERWT14F) to account for the complex sampling design.

Three attitudinal variables in a self-administered questionnaire (SAQ) were used to measure the respondents' attitude towards risk and uncertainty. The respondents were asked to rate their agreements on following statements: 1) I'm healthy enough that I really don't need health insurance; 2) Health insurance is not worth the money its costs; and 3) I'm more likely to take risks than the average person. The first statement measures the demand for health insurance and the second statement measures its perceived value, determined on the basis of the trade-off between loss and gain associated with purchasing the product. ${ }^{15}$ These variables measure how much individuals felt "loss" from buying health insurance. The third statement measures the individual's risk preferences. The estimates were weighted using the SAQ weight variable (SAQWT14F).

All three variables used five-point Likert scale (strongly disagree, somewhat disagree, uncertain, somewhat agree, strongly agree). We grouped strongly and somewhat disagree into "disagreed" and strongly and somewhat agree into "agreed". The percentage of people in each group was presented by insurance status.

Observations with missing values for any variable were not included in the analyses. Difference in all socio-demographic and attitudinal variables were analyzed between the uninsured and the insured groups, using chi-square test. P-values were adjusted for multiple comparisons using the Bonferroni correction. The binary variable of insurance status was regressed on three attitudinal variables and socio-demographic characteristics using a logit model. The odds ratios (OR) with $95 \%$ confidence interval were reported. All analyses were performed using SAS version 9.4 (SAS Institute, Cary, NC, USA).

\section{Results}

The data included 34,875 individuals, of which 20,898 were nonelderly adults who were 18 to 64 years old. About four in ten of nonelderly adults earned income with 138 to $400 \%$ of FPL, thereby being eligible for marketplace premium subsidies $(n=9,162)$. Final sample had 4,848 individuals after excluding those who were provided with health insurance from their employers and those with public insurance (Figure 1).

The uninsured rates varied across the populations. Weighted to represent the U.S. population, the estimated percentage of the uninsured for all individuals $(n=34,875)$ was $9.8 \%$ and went up to $14.3 \%$ for nonelderly adults $(n=20,898)$. The rate increased to $17.2 \%$ for nonelderly adults eligible for marketplace federal subsidies $(n=9,162)$ and further increased to $31.1 \%$ for those who were eligible neither public coverage nor ESI $(n=4,848)$ 
(Figure 1). The uninsured rate among children was $3.5 \%$ $(n=9,300)$.

Table 1 shows the characteristics of the study sample by insurance status. Weighted to represent the U.S. population, nearly a quarter belonged to the Hispanic ethnicity (23.9\%). About four in ten individuals were between $25-44$ years old (43.7\%), earned income between $\$ 44,725$ and $\$ 82,006(43.2 \%)$, lived in South region (41.9\%), and did not have an office-based provider's visit (40.4\%) within the past 12 months. About half of the sample were females (51.6\%), continuously employed within the past 12 months (55.2\%), received high school degree or less than high school education (46.9\%), and did not refill prescription medications (48.8\%) within the past 12 months. Six in ten of individuals rated their health status as very good or excellent (60.2\%).

The rates of uninsured adults were significantly different from the rates of insured adults in all the demographic categories and health utilization patterns. Substantially higher proportion of the uninsured adults than the insured ones belonged to Hispanic ethnicity ( $41.7 \%$ vs $15.8 \%$; $<<0.001)$. About half the uninsured adults (51.9\%) belonged to the age group between from 25 to 44 years, as compared to $40.0 \%$ for the insured ones. About $65.2 \%$ of the uninsured adults were employed, compared to $50.7 \%$ for the insured group. Significantly higher proportion of the uninsured adults $(62.2 \%)$ than the insured adults (40.0\%) received education less than high school or graduated from high school $(p<0.001)$. Also, substantially higher proportion of the uninsured adults (61.4\%) than the insured ones (30.9\%) did not visit an office-based provider $(p<0.001)$ and nearly seven in ten of the uninsured adults did not refill prescription drugs (68.0\%) within the past 12 months. Higher proportion of the insured adults (62.0\%) rated their health status as very good or excellent than the uninsured ones $(56.0 \%)$ and this difference was found to be significant as well $(p<0.001)$.

The uninsured adults agreed or strongly agreed that they do not need health insurance as opposed to the insured ones $(28.2 \%$ vs $16.3 \% ; p<0.001$ ) and that health insurance is not worth its cost about 10 percentage points more than the insured ones (38.7\% vs $27.9 \%$; $p<0.001$ ). In addition, the uninsured adults appeared to be more risk takers than the insured ones $(27.8 \%$ vs $22.1 \%$; $p<0.001$ ).

Table 2 presents odds ratio from a logit model associated with likelihood of being uninsured among nonelderly adults living in poverty without ESI coverage. Low demand of health insurance (OR: $1.18,95 \% \mathrm{Cl}: 1.10-1.26)$ and low perceived value of health insurance (OR: 1.11, 95\% Cl: 1.04-1.18) were statistically significantly associated with higher likelihood to be uninsured, but risk taking was not found to be a significant factor.
Additionally, individuals who did not visit an office-based provider (OR: $2.51,95 \% \mathrm{Cl}: 2.08-3.03$ ) and did not refill their prescription drugs (OR: $1.59,95 \% \mathrm{Cl}: 2.08-3.03$ ) at all within the past 12 months, were more likely to be uninsured. Furthermore, individuals with poorer health status were more likely to be uninsured (OR: $0.84,95 \% \mathrm{Cl}: 0.77-0.91$ ). Also, the Hispanic ethnicity was found to be strongly associated with the likelihood of being uninsured (OR: 2.53, 95\% Cl: 2.15-2.98). Moreover, males than females, older adults aged 25-64 years, than younger adults aged 18-24 years, people with lower incomes or lower educational achievements, and the employed than the unemployed; were more likely to be uninsured. The model fitted the data better than the null model $\left(\chi^{2}=961.4\right.$, $d f=18, p<0.001$ ).

\section{Discussion}

This study is the first to estimate the uninsured rate among nonelderly adults living in poverty without employer-sponsored insurance sources - the population of ACA's greatest interest. We found that three in ten of those were continuously uninsured for 2014 despite substantial amount of federal financial assistance that was offered under the ACA. We also found that individuals not much valuing health insurance and rarely utilizing health care were more likely to be uninsured, providing a possible explanation of much higher uninsured rate than overall uninsured rate $(9.8 \%)$.

The uninsured and the insured adults largely differed in their demographic characteristics and health care utilization patterns. The uninsured were more likely to be Hispanics, employed, younger adults, less educated, earned low incomes, and lived in South, consistent with previous studies. ${ }^{7,12,13}$ Our multivariate analyses results also indicated that demographic characteristics were significantly associated with likelihood of being uninsured. In addition, individuals without a provider's visit or prescription refills within the past 12 months and those with lower health status were more likely to be uninsured.

These findings collectively suggest that adverse selection may be happening in the marketplace. Adverse selection occurs when people self-select to purchase health insurance knowing that they are likely to use the insurance in future based on the knowledge of their health status - a greater likelihood of being uninsured among younger and healthier people, who do not use health care, provides a typical example of adverse selection. As our study does not infer causality, one may argue that our results suggest limited access to health care among the uninsured rather than adverse selection. Given that individuals with poor health were also more likely to be uninsured, adverse selection would be a more reasonable approach to interpret our findings.

Adverse selection observed in marketplace indicates that people in poverty hardly responded to the individual mandate 
and financial assistance, which was expected to shift their reference point for enrollment decision to initial wealth minus premiums. Consequently, it appears that they still feel premiums as "losses" and hence, decide to remain uninsured. Our results show that a greater proportion of the uninsured adults than the insured adults agreed or strongly agreed that health insurance is not worth its cost.

The weak response by the people in poverty to the new policy is probably because they were unaware of the individual mandate and financial assistance. The Commonwealth Fund ACA Tracking Survey reported that only about half of the respondents were aware of existence of marketplace and financial assistance. ${ }^{16}$ Furthermore, the Kaiser report indicated that one in five uninsured adults did not know that having health insurance is now mandatory. ${ }^{17}$ Many uninsured have lived without health insurance for years ${ }^{16}$ so they might have been excluded of our outreach efforts. Lack of awareness in the early phase of the new policy implementation is not uncommon-nearly half of Medicare beneficiaries had little or no knowledge about Medicare Part D, shortly after it was introduced. ${ }^{18}$

Another explanation could be the limited understanding of health insurance in general. One research of noninstitutionalized adults aged 25-64 years showed that only $14 \%$ were correct about four basic insurance terms: deductibles, copayments, coinsurance, and maximum out-of-pocket costs, ${ }^{19}$ and similar results were found with another study of people with employer-sponsored insurance. ${ }^{20}$ Health insurance literacy, "knowledge, ability, and confidence to effectively choose and use health insurance", ${ }^{21}$ was recognized as one of key factors that lead to success of the ACA..$^{22}$ One study found that the six in ten uninsured did not know the premiums need to be paid every month. ${ }^{22}$ With such lack of knowledge, people will not be able to behave in a way that the policy encourages.

Finally, the risk preference was not significantly associated with the likelihood of being uninsured. This finding indicated that people remained uninsured not because they are risk takers as suggested by the expected utility mode ${ }^{23}$ rather because they feel "losses" relative to their reference points.

Managing the adverse selection is critical for the marketplace's success. Our study emphasizes the need for increasing the perceived value of health insurance to reduce uninsured rate among the people with no other insurance sources than marketplace. More rigorous, and targeted outreach efforts to raise awareness of financial assistance and individual mandate are required and will help people in poverty understand the value of health insurance better. Shi et al. noted that individuals were likely to respond to the presence of penalty rather than the amount of penalty. ${ }^{12}$ The outreach efforts should focus not only on providing information tailored to their insurance literacy but also establishing a new social norm of health insurance: buying health insurance is not optional. People tend to be influenced by friends and family, sometimes more than by experts, and follow social norms. ${ }^{24-25}$ This new social norm or new reference point will be key to the success of insurance marketplace, especially with the recent tax reform of removing the penalty component from the ACA.

\section{Limitations}

The data for MEPS-HC did not have information on states so our study used $138 \%$ to $400 \%$ of FPL to identify people who are eligible for premium subsidies. As of January 1, 2014, 26 states decided to expand Medicaid eligibility, so our sample did not include people with income $100-138 \%$ of FPL in 25 states not adopting Medicaid expansion, so our findings may not be generalized to this population. Also, we categorized the persons who have health insurance as the insured without differentiating new enrollees from those who have been insured. So past experiences with health insurance might have influenced the scores of attitudinal variables among the insured. In addition, we identified people working for the firms that provide health insurances based on their current main job. Some people may have obtained their health insurances through other jobs, but it is very unlikely. About a quarter of the sample had missing values for three attitudinal variables, but there is little concern of selection bias as characteristics of missing data were not significantly different from the sample characteristics. Lastly, there could be recall bias because the data were collected retrospectively.

Acknowledgements: This research received no specific grant from any funding agency in the public, commercial, or not-forprofit sectors. The author thanks Julie Urmie, Ph.D. for her valuable comments on earlier version of this manuscript.

Conflict of interests: None declared.

\section{References}

1. Obamacare mandate: exemption and tax penalty. Obamacare facts.

https://obamacarefacts.com/obamacare-mandateexemption-penalty/ Accessed August 10, 2017.

2. Henry J. Kaiser Family Foundation. The uninsured: a primer. Key facts about health insurance and the uninsured in the era of health reform.

http://www.kff.org/uninsured/report/the-uninsureda-primer-key-facts-about-health-insurance-and-theuninsured-in-the-wake-of-national-health-reform/ Published in November 2016. Accessed August 2, 2017.

3. Sydnor, J. (Over)insuring Modest Risks. American Economic Journal: Applied Economics. 2010; 2(4): 177-199.

4. Hu W, Scott JS. Behavioral Obstacles in the Annuity Market. Financial Analysts Journal. 2007; 63(6): 7182. 
5. Baicker K, Congdon WJ, Mullainathan S. Health insurance coverage and take-up: lessons from behavioral economics. The Milbank Quarterly. 2012; 90(1): 107-134.

6. Eckles DL, Wise JV. Prospect theory and the demand for insurance. The Risk Theory Society, American Risk and Insurance Association (ARIA), Philadelphia, PA USA, available at: available at: http://www. aria. org/rts/proceedings/2012/default. htm (last access: September 29, 2017).

7. Kaies-Schwarz N, Kokot J, Vomhof M, Weßling J. Health insurance choice and risk preferences under cumulative prospect theory - an experiment. Journal of Economic Behavior \& Organization. 2017; 137: 374-397

8. Kahneman D, Tversky A. Prospect theory: an analysis of decision under risk. Econometrica.1979; 47(2): 263292.

9. Tversky A, Kahneman D. Advances in prospect theory: cumulative representation of uncertainty. Journal of Risk and Uncertainty. 1992; 5: 297-323.

10. Cutler DM, Zeckhauser RJ. Adverse selection in health insurance. Forum Health Econ Pol. 1998; 1(1): 488500.

11. Hackmann MB, Kolstad JT, Kowalski AE. Adverse selection and an individual mandate: when theory meets practice. Am Econ Rev. 2015 March; 105 (3): 1030-1066.

12. Shi L, Feng C, Griffin S, Williams JE, Crandall LA, Truong K. Does awareness of the Affordable Care Act reduce averse selection? A study of the long-term uninsured in South Carolina. Inquiry: The Journal of Health Care Organization, Provision, and Financing. 2017; 54: 1-7. doi: 10.1177/0046958017727103

13. Cantiello J, Fottler MD, Oetjen D, Zhan NJ. The impact of demographic and perceptual variables on young adult's decision to be covered by private health insurance. BMC Health Services Research. 2015; 15: 195

14. Monheit AC, Vistnes JP. Health insurance enrollment decisions: preferences for coverage, worker sorting, and insurance take-up. Inquiry. Summer 2008; 45 : 153-167.

15. ZeithamI VA. Consumer perceptions of price, quality, and value: a means-end model and synthesis of evidence. Journal of Marketing. 1988 July; 52:2-22.

16. The Commonwealth Fund. Affordable Care Act tracking survey: most adults with marketplace or Medicaid coverage continue to be satisfied with their health insurance but many remain uninsured. http://acatracking.commonwealthfund.org/ Accessed August 17, 2017.

17. Henry J. Kaiser Family Foundation. Kaiser health tracking poll: December 2015. http://www.kff.org/health-costs/poll-finding/kaiserhealth-tracking-poll-december-2015/ Published in December 2015. Accessed August 16, 2017.

18. Heiss F, McFadden D, Winter J. Who failed to enroll in Medicare Part D, and why? Early results. Health Affairs. 2006; 25(5): w344-w354.

19. Loewenstein G, Friedman JY, McGill B, et al. Consumers' misunderstanding of health insurance. Journal of Health Economics. 2013; 32(5): 850-862.

20. Handel BR, Kolstad JT. Health insurance for" humans": information frictions, plan choice, and consumer welfare. The American Economic Review. 2015; 105(8): 2449-2500.

21. Kim J, Braun B, Williams AD. Understanding health insurance literacy: A literature review. Family and Consumer Sciences Research Journal. 2013; 42(1): 313.

22. Levitt $\mathrm{L}$. Why health insurance literacy matters. JAMA. 2015; 313(6):555-556.

23. Friedman B. Risk aversion and the consumer choice of health insurance option. The review of economics and statistics. 1974 May; 56(2): 209-214.

24. Slovic P, Fischhoff B, Lichtenstein S, Corrigan B, Combs B. Preference for insuring against probable small losses: insurance implications. The Journal of Risk and Insurance. 1977; 44(2): 237-258.

25. Edgman-Levitan S. Cleary PD. What information do consumers want and need? Health Affairs. 1996; 15(4): 42-56. 
Figure 1. Sampling frame and uninsured rates

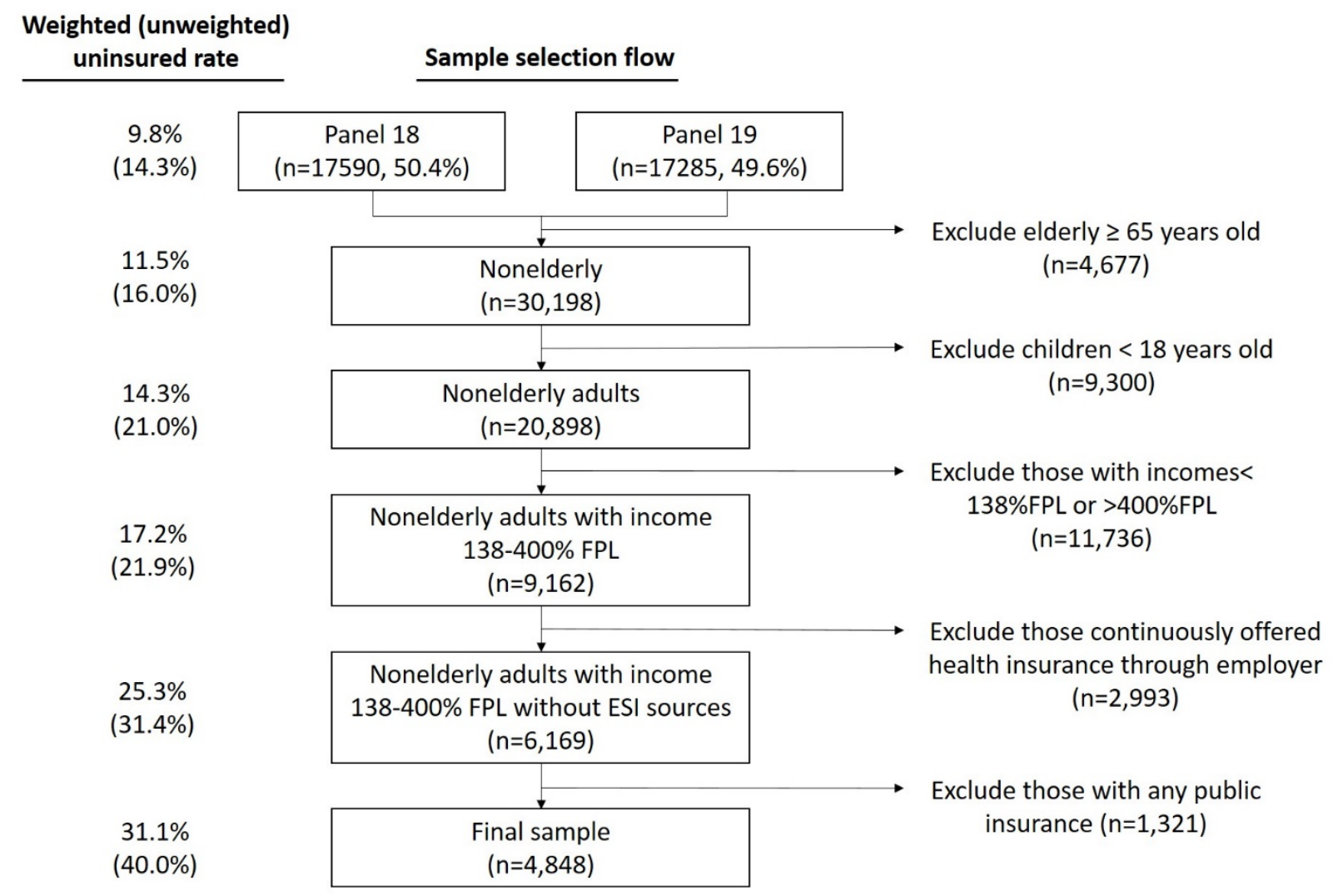

Note. Unweighted and weighted uninsured rates represent the raw estimate and the estimate adjusted by person-level weight variable. ESI: employer-sponsored insurance, FPL: federal poverty level. 
Table 1. Sample characteristics by insurance status $(n=4,848)$

\begin{tabular}{|c|c|c|c|c|c|c|c|}
\hline \multirow[b]{2}{*}{ Variables } & \multicolumn{2}{|c|}{ All } & \multicolumn{2}{|c|}{ Uninsured } & \multicolumn{2}{|c|}{ Insured } & \multirow[t]{2}{*}{ P-value } \\
\hline & Unweighted & Weighted & $\begin{array}{c}\text { Unweighted } \\
\text { n (\%) }\end{array}$ & $\begin{array}{l}\text { Weighted } \\
\text { n (\%) }\end{array}$ & $\begin{array}{l}\text { Unweighted } \\
\text { n (\%) }\end{array}$ & $\begin{array}{l}\text { Weighted } \\
\text { n (\%) }\end{array}$ & \\
\hline $\begin{array}{l}\text { Continuously insured for } \\
2014\end{array}$ & 4848 & 40681985 & $\begin{array}{c}1938 \\
(40.0 \%)\end{array}$ & $\begin{array}{c}12633284 \\
(31.1 \%) \\
\end{array}$ & $\begin{array}{c}2910 \\
(60.0 \%)\end{array}$ & $\begin{array}{c}28048701 \\
(68.9 \%) \\
\end{array}$ & \\
\hline \multicolumn{8}{|l|}{ Poverty } \\
\hline $138-250 \% \mathrm{FPL}$ & $\begin{array}{c}2662 \\
(54.9 \%)\end{array}$ & $\begin{array}{c}20558162 \\
(50.5 \%)\end{array}$ & $\begin{array}{c}1292 \\
(66.7 \%)\end{array}$ & $\begin{array}{l}8138518 \\
(64.4 \%)\end{array}$ & $\begin{array}{c}1370 \\
(47.1 \%)\end{array}$ & $\begin{array}{c}12420000(4 \\
4.3 \%)\end{array}$ & $<0.001$ \\
\hline $250-400 \% \mathrm{FPL}$ & $\begin{array}{c}2186 \\
(45.1 \%)\end{array}$ & $\begin{array}{c}20123823 \\
(49.5 \%)\end{array}$ & $\begin{array}{c}646 \\
(33.3 \%)\end{array}$ & $\begin{array}{l}4494767 \\
(35.6 \%)\end{array}$ & $\begin{array}{c}1540 \\
(52.9 \%)\end{array}$ & $\begin{array}{c}15630000 \\
(55.7 \%)\end{array}$ & \\
\hline Age & & & & & & & $<0.001$ \\
\hline $18-24$ & $\begin{array}{c}1034 \\
(21.3 \%)\end{array}$ & $\begin{array}{l}9085428 \\
(22.3 \%)\end{array}$ & $\begin{array}{c}323 \\
(16.7 \%)\end{array}$ & $\begin{array}{l}2081958 \\
(16.5 \%)\end{array}$ & $\begin{array}{c}711 \\
(24.4 \%)\end{array}$ & $\begin{array}{l}703470 \\
(25.0 \%)\end{array}$ & \\
\hline $25-44$ & $\begin{array}{c}2217 \\
(45.7 \%)\end{array}$ & $\begin{array}{c}17784355 \\
(43.7 \%) \\
\end{array}$ & $\begin{array}{c}1035 \\
(53.4 \%)\end{array}$ & $\begin{array}{c}6554626 \\
(51.9 \%) \\
\end{array}$ & $\begin{array}{c}1182 \\
(40.6 \%)\end{array}$ & $\begin{array}{c}11230000 \\
(40.0 \%)\end{array}$ & \\
\hline $45-64$ & $\begin{array}{c}1597 \\
(32.9 \%)\end{array}$ & $\begin{array}{c}13812202 \\
(34.0 \%)\end{array}$ & $\begin{array}{c}580 \\
(29.9 \%)\end{array}$ & $\begin{array}{c}3996700 \\
(31.6 \%)\end{array}$ & $\begin{array}{c}1017 \\
(35.0 \%)\end{array}$ & $\begin{array}{c}9815502 \\
(35.0 \%)\end{array}$ & \\
\hline Gender & & & & & & & $<0.001$ \\
\hline Male & $\begin{array}{c}2406 \\
(49.6 \%) \\
\end{array}$ & $\begin{array}{c}19709756 \\
(8.5 \%)\end{array}$ & $\begin{array}{c}1147 \\
(59.2 \%)\end{array}$ & $\begin{array}{l}761772 \\
(60.3 \%) \\
\end{array}$ & $\begin{array}{c}1259 \\
(43.3 \%) \\
\end{array}$ & $\begin{array}{c}12090000 \\
(43.1 \%)\end{array}$ & \\
\hline Female & $\begin{array}{c}2442 \\
(50.4 \%)\end{array}$ & $\begin{array}{c}20972229 \\
(51.6 \%) \\
\end{array}$ & $\begin{array}{c}791 \\
(40.8 \%) \\
\end{array}$ & $\begin{array}{c}5011512 \\
(39.7 \%) \\
\end{array}$ & $\begin{array}{c}1651 \\
(56.7 \%) \\
\end{array}$ & $\begin{array}{c}15960000 \\
(56.9 \%)\end{array}$ & \\
\hline Ethnicity & & & & & & & $<0.001$ \\
\hline Hispanic & $\begin{array}{c}1864 \\
(38.5 \%)\end{array}$ & $\begin{array}{c}9703213 \\
(23.9 \%) \\
\end{array}$ & $\begin{array}{c}1055 \\
(54.4 \%)\end{array}$ & $\begin{array}{c}5272097 \\
(41.7 \%) \\
\end{array}$ & $\begin{array}{c}809 \\
(27.8 \%)\end{array}$ & $\begin{array}{l}4431116 \\
(15.8 \%)\end{array}$ & \\
\hline $\begin{array}{l}\text { Non- } \\
\text { Hispanic }\end{array}$ & $\begin{array}{c}2984 \\
(61.6 \%)\end{array}$ & $\begin{array}{c}30978772 \\
(76.2 \%)\end{array}$ & $\begin{array}{c}883 \\
(15.6 \%)\end{array}$ & $\begin{array}{c}7361187 \\
(58.3 \%)\end{array}$ & $\begin{array}{c}2101 \\
(72.2 \%)\end{array}$ & $\begin{array}{c}23620000 \\
(84.2 \%)\end{array}$ & \\
\hline Employment status & & & & & & & $<0.001$ \\
\hline Employed & $\begin{array}{c}2661 \\
(54.9 \%)\end{array}$ & $\begin{array}{c}22444511 \\
(55.2 \%)\end{array}$ & $\begin{array}{c}1220 \\
(63.0 \%)\end{array}$ & $\begin{array}{c}8234153 \\
(65.2 \%) \\
\end{array}$ & $\begin{array}{c}1441 \\
(54.2 \%)\end{array}$ & $\begin{array}{c}14210000 \\
(50.7 \%)\end{array}$ & \\
\hline Unemployed & $\begin{array}{c}2011 \\
(41.5 \%) \\
\end{array}$ & $\begin{array}{c}18192018 \\
(44.7 \%)\end{array}$ & $\begin{array}{c}623 \\
(32.2 \%) \\
\end{array}$ & $\begin{array}{c}4393357 \\
(34.8 \%) \\
\end{array}$ & $\begin{array}{c}1388 \\
(47.7 \%)\end{array}$ & $\begin{array}{c}13800000 \\
(49.2 \%)\end{array}$ & \\
\hline Missing & $\begin{array}{c}176 \\
(3.6 \%)\end{array}$ & $\begin{array}{c}45456.62 \\
(0.1 \%) \\
\end{array}$ & $\begin{array}{c}95 \\
(4.9 \%) \\
\end{array}$ & $\begin{array}{c}5774.18 \\
(0.1 \%) \\
\end{array}$ & $\begin{array}{c}81 \\
(2.8 \%) \\
\end{array}$ & $\begin{array}{c}39682.4 \\
(0.1 \%) \\
\end{array}$ & \\
\hline Education & & & & & & & $<0.001$ \\
\hline HS or less & $\begin{array}{c}2525 \\
(52.1 \%)\end{array}$ & $\begin{array}{c}19071368 \\
(46.9 \%)\end{array}$ & $\begin{array}{c}1259 \\
(65.0 \%)\end{array}$ & $\begin{array}{c}7859595 \\
(62.2 \%)\end{array}$ & $\begin{array}{c}1266 \\
(43.5 \%)\end{array}$ & $\begin{array}{c}11210000 \\
(40.0 \%)\end{array}$ & \\
\hline Beyond HS & $\begin{array}{c}2011 \\
(41.5 \%)\end{array}$ & $\begin{array}{c}21353096 \\
(52.5 \%)\end{array}$ & $\begin{array}{c}623 \\
(32.2 \%)\end{array}$ & $\begin{array}{c}4585167 \\
(36.3 \%)\end{array}$ & $\begin{array}{c}1629 \\
(56.0 \%)\end{array}$ & $\begin{array}{c}16770000 \\
(59.8 \%)\end{array}$ & \\
\hline Missing & $\begin{array}{c}176 \\
(3.6 \%)\end{array}$ & $\begin{array}{c}257520.7 \\
(0.6 \%)\end{array}$ & $\begin{array}{c}56 \\
(2.9 \%)\end{array}$ & $\begin{array}{c}188523 \\
(1.5 \%)\end{array}$ & $\begin{array}{c}15 \\
(0.5 \%)\end{array}$ & $\begin{array}{c}68998.1 \\
(0.3 \%)\end{array}$ & \\
\hline
\end{tabular}




\begin{tabular}{|c|c|c|c|c|c|c|c|}
\hline \multicolumn{7}{|l|}{ Income } & \multirow[t]{2}{*}{$<0.001$} \\
\hline$\$ 1-\$ 22,200$ & $\begin{array}{c}303 \\
(6.3 \%) \\
\end{array}$ & $\begin{array}{c}2486864 \\
(6.1 \%) \\
\end{array}$ & $\begin{array}{c}159 \\
(8.2 \%) \\
\end{array}$ & $\begin{array}{c}1079247 \\
(8.5 \%) \\
\end{array}$ & $\begin{array}{c}144 \\
(5.0 \%) \\
\end{array}$ & $\begin{array}{c}1407617 \\
(5.0 \%) \\
\end{array}$ & \\
\hline $\begin{array}{l}\$ 22,201- \\
\$ 44,724\end{array}$ & $\begin{array}{c}1777 \\
(36.7 \%)\end{array}$ & $\begin{array}{c}15208167 \\
(37.4 \%)\end{array}$ & $\begin{array}{c}829 \\
(42.8 \%)\end{array}$ & $\begin{array}{c}5739873 \\
(45.4 \%)\end{array}$ & $\begin{array}{c}948 \\
(32.6 \%)\end{array}$ & $\begin{array}{c}9468294 \\
(33.8 \%)\end{array}$ & \\
\hline $\begin{array}{l}\$ 44,725- \\
\$ 82,006\end{array}$ & $\begin{array}{c}2125 \\
(43.8 \%)\end{array}$ & $\begin{array}{c}17559132 \\
(43.2 \%) \\
\end{array}$ & $\begin{array}{c}742 \\
(38.3 \%)\end{array}$ & $\begin{array}{c}4541879 \\
(36.0 \%)\end{array}$ & $\begin{array}{c}1383 \\
(47.5 \%)\end{array}$ & $\begin{array}{c}13020000 \\
(46.4 \%)\end{array}$ & \\
\hline $\begin{array}{l}\$ 82,007 \text { or } \\
\text { more }\end{array}$ & $\begin{array}{c}643 \\
(13.3 \%) \\
\end{array}$ & $\begin{array}{c}5427822 \\
(13.3 \%) \\
\end{array}$ & $\begin{array}{c}208 \\
(10.7 \%) \\
\end{array}$ & $\begin{array}{c}1272284 \\
(10.1 \%) \\
\end{array}$ & $\begin{array}{c}435 \\
(15.0 \%) \\
\end{array}$ & $\begin{array}{c}4155538 \\
(14.8 \%) \\
\end{array}$ & \\
\hline \multicolumn{7}{|l|}{ Region } & $<0.001$ \\
\hline Northeast & $\begin{array}{c}616 \\
(12.7 \%) \\
\end{array}$ & $\begin{array}{c}5694686 \\
(14.0 \%) \\
\end{array}$ & $\begin{array}{c}206 \\
(10.6 \%) \\
\end{array}$ & $\begin{array}{c}1459764 \\
(11.6 \%) \\
\end{array}$ & $\begin{array}{c}410 \\
(14.1 \%) \\
\end{array}$ & $\begin{array}{l}234922 \\
(15.1 \%) \\
\end{array}$ & \\
\hline Midwest & $\begin{array}{c}808 \\
(16.7 \%) \\
\end{array}$ & $\begin{array}{c}8076425 \\
(19.9 \%)\end{array}$ & $\begin{array}{c}264 \\
(13.6 \%) \\
\end{array}$ & $\begin{array}{c}2062163 \\
(16.3 \%)\end{array}$ & $\begin{array}{c}544 \\
(18.7 \%) \\
\end{array}$ & $\begin{array}{c}6014262 \\
(21.4 \%) \\
\end{array}$ & \\
\hline South & $\begin{array}{c}2034 \\
(42.0 \%) \\
\end{array}$ & $\begin{array}{c}17027871 \\
(41.9 \%) \\
\end{array}$ & $\begin{array}{c}901 \\
(46.5 \%) \\
\end{array}$ & $\begin{array}{c}5933865 \\
(47.0 \%) \\
\end{array}$ & $\begin{array}{c}1133 \\
(38.9 \%)\end{array}$ & $\begin{array}{c}11090000 \\
(39.6 \%)\end{array}$ & \\
\hline West & $\begin{array}{c}1390 \\
(28.7 \%)\end{array}$ & $\begin{array}{c}9883004 \\
(24.3 \%)\end{array}$ & $\begin{array}{c}567 \\
(29.3 \%)\end{array}$ & $\begin{array}{c}3177491 \\
(25.2 \%)\end{array}$ & $\begin{array}{c}823 \\
(28.3 \%)\end{array}$ & $\begin{array}{c}6705512 \\
(23.9 \%)\end{array}$ & \\
\hline \multicolumn{7}{|l|}{ Self-reported health status } & $<0.001$ \\
\hline Excellent & $\begin{array}{c}907 \\
(18.7 \%) \\
\end{array}$ & $\begin{array}{c}9847356 \\
(24.5 \%) \\
\end{array}$ & $\begin{array}{c}370 \\
(19.1 \%) \\
\end{array}$ & $\begin{array}{c}3165288 \\
(25.3 \%)\end{array}$ & $\begin{array}{c}537 \\
(18.5 \%) \\
\end{array}$ & $\begin{array}{c}6682069 \\
(24.1 \%) \\
\end{array}$ & \\
\hline Very good & $\begin{array}{c}1302 \\
(26.9 \%) \\
\end{array}$ & $\begin{array}{c}14347927 \\
(35.7 \%) \\
\end{array}$ & $\begin{array}{c}430 \\
(22.2 \%) \\
\end{array}$ & $\begin{array}{c}3842977 \\
(30.7 \%) \\
\end{array}$ & $\begin{array}{c}872 \\
(30.0 \%) \\
\end{array}$ & $\begin{array}{c}10500000 \\
(37.9 \%) \\
\end{array}$ & \\
\hline Good & $\begin{array}{c}1204 \\
(24.8 \%)\end{array}$ & $\begin{array}{c}11285120 \\
(28.0 \%)\end{array}$ & $\begin{array}{c}514 \\
(26.5 \%)\end{array}$ & $\begin{array}{c}3959398 \\
(31.6 \%)\end{array}$ & $\begin{array}{c}690 \\
(23.7 \%)\end{array}$ & $\begin{array}{c}7325722 \\
(26.4 \%)\end{array}$ & \\
\hline Fair & $\begin{array}{c}411 \\
(8.5 \%) \\
\end{array}$ & $\begin{array}{c}3734114 \\
(9.3 \%) \\
\end{array}$ & $\begin{array}{c}162 \\
(8.4 \%) \\
\end{array}$ & $\begin{array}{c}1172257 \\
(9.4 \%) \\
\end{array}$ & $\begin{array}{c}249 \\
(8.6 \%) \\
\end{array}$ & $\begin{array}{c}2561857 \\
(9.2 \%) \\
\end{array}$ & \\
\hline Poor & $\begin{array}{c}56 \\
(1.2 \%) \\
\end{array}$ & $\begin{array}{c}629469.9 \\
(9.3 \%) \\
\end{array}$ & $\begin{array}{c}18 \\
(0.9 \%)\end{array}$ & $\begin{array}{c}190391 \\
(1.5 \%) \\
\end{array}$ & $\begin{array}{c}38 \\
(1.3 \%) \\
\end{array}$ & $\begin{array}{c}439079 \\
(1.6 \%) \\
\end{array}$ & \\
\hline Missing & $\begin{array}{c}968 \\
(20.0 \%) \\
\end{array}$ & $\begin{array}{c}406071.4 \\
(1.0 \%) \\
\end{array}$ & $\begin{array}{c}444 \\
(22.9 \%) \\
\end{array}$ & $\begin{array}{c}203097 \\
(1.6 \%) \\
\end{array}$ & $\begin{array}{c}524 \\
(18.0 \%) \\
\end{array}$ & $\begin{array}{c}202975 \\
(0.7 \%) \\
\end{array}$ & \\
\hline \multicolumn{7}{|c|}{ Provider visit within the past 12 months } & $<0.001$ \\
\hline Never visited & $\begin{array}{c}2343 \\
(48.3 \%) \\
\end{array}$ & $\begin{array}{c}16429911 \\
(40.4 \%) \\
\end{array}$ & $\begin{array}{c}1336 \\
(68.9 \%) \\
\end{array}$ & $\begin{array}{c}7759184 \\
(61.4 \%) \\
\end{array}$ & $\begin{array}{c}1007 \\
(34.6 \%)\end{array}$ & $\begin{array}{c}8670727 \\
(30.9 \%) \\
\end{array}$ & \\
\hline $\begin{array}{l}\text { Visited at least } \\
\text { once }\end{array}$ & $\begin{array}{c}2505 \\
(51.7 \%) \\
\end{array}$ & $\begin{array}{c}24252074 \\
(59.6 \%) \\
\end{array}$ & $\begin{array}{c}602 \\
(31.1 \%)\end{array}$ & $\begin{array}{c}4874100 \\
(38.6 \%) \\
\end{array}$ & $\begin{array}{c}1903 \\
(65.4 \%)\end{array}$ & $\begin{array}{c}19380000 \\
(69.1 \%)\end{array}$ & \\
\hline \multicolumn{7}{|c|}{ Prescription drug refill within the past 12 months } & $<0.001$ \\
\hline Never refilled & $\begin{array}{c}2708 \\
(55.9 \%) \\
\end{array}$ & $\begin{array}{c}19858208 \\
(48.8 \%) \\
\end{array}$ & $\begin{array}{c}1414 \\
(73.0 \%) \\
\end{array}$ & $\begin{array}{c}8588436 \\
(68.0 \%) \\
\end{array}$ & $\begin{array}{c}1294 \\
(44.5 \%) \\
\end{array}$ & $\begin{array}{c}11270000 \\
(40.2 \%)\end{array}$ & \\
\hline $\begin{array}{l}\text { Refilled at least } \\
\text { once }\end{array}$ & $\begin{array}{c}2140 \\
(44.1 \%)\end{array}$ & $\begin{array}{c}20823777 \\
(51.2 \%) \\
\end{array}$ & $\begin{array}{c}524 \\
(27.0 \%) \\
\end{array}$ & $\begin{array}{c}4044848 \\
(32.0 \%)\end{array}$ & $\begin{array}{c}1616 \\
(55.5 \%)\end{array}$ & $\begin{array}{c}16780000 \\
(59.8 \%)\end{array}$ & \\
\hline
\end{tabular}

Note. The percentages represent the proportion of indicated responses in each item. They were weighted using person weight variable. Missing data include responses coded as don't know, inapplicable, not ascertained. Variables without missing category did not have any missing values. ESI: employer-sponsored insurance, FPL: federal poverty level, HS: high school. 
Table 2. Attitudinal variables by insurance status $(n=4,848)$

\begin{tabular}{|c|c|c|c|c|c|c|c|}
\hline \multirow[b]{2}{*}{ Variables } & \multicolumn{2}{|c|}{ All } & \multicolumn{2}{|c|}{ Uninsured } & \multicolumn{2}{|c|}{ Insured } & \multirow[t]{2}{*}{ P-value } \\
\hline & Unweighted & Weighted & $\begin{array}{c}\text { Unweighted } \\
\text { n (\%) }\end{array}$ & $\begin{array}{c}\text { Weighted } \\
\text { n (\%) }\end{array}$ & $\begin{array}{c}\text { Unweighted } \\
\text { n (\%) }\end{array}$ & $\begin{array}{c}\text { Weighted } \\
\text { n (\%) }\end{array}$ & \\
\hline \multicolumn{7}{|c|}{ Do not need health insurance } & $<0.001$ \\
\hline Disagreed & $\begin{array}{c}2528 \\
(52.2 \%)\end{array}$ & $\begin{array}{c}25983991 \\
(64.6 \%)\end{array}$ & $\begin{array}{c}822 \\
(42.4 \%)\end{array}$ & $\begin{array}{c}6349551 \\
(50.7 \%)\end{array}$ & $\begin{array}{c}1706 \\
(58.6 \%)\end{array}$ & $\begin{array}{c}19630000 \\
(70.8 \%)\end{array}$ & \\
\hline Uncertain & $\begin{array}{c}457 \\
(9.4 \%)\end{array}$ & $\begin{array}{c}4726435 \\
(11.7 \%)\end{array}$ & $\begin{array}{c}228 \\
(11.8 \%)\end{array}$ & $\begin{array}{c}2069350 \\
(16.5 \%)\end{array}$ & $\begin{array}{c}229 \\
(7.9 \%)\end{array}$ & $\begin{array}{c}2657085 \\
(9.6 \%)\end{array}$ & \\
\hline Agreed & $\begin{array}{c}789 \\
(16.3 \%)\end{array}$ & $\begin{array}{c}8062779 \\
(20.0 \%)\end{array}$ & $\begin{array}{c}397 \\
(20.5 \%)\end{array}$ & $\begin{array}{c}3533532 \\
(28.2 \%)\end{array}$ & $\begin{array}{c}392 \\
(13.5 \%)\end{array}$ & $\begin{array}{c}4529247 \\
(16.3 \%)\end{array}$ & \\
\hline Missing & $\begin{array}{c}1074 \\
(22.2 \%)\end{array}$ & $\begin{array}{c}1476853 \\
(3.7 \%)\end{array}$ & $\begin{array}{c}491 \\
(25.3 \%)\end{array}$ & $\begin{array}{c}580974 \\
(4.6 \%)\end{array}$ & $\begin{array}{c}583 \\
(20.0 \%)\end{array}$ & $\begin{array}{c}895879 \\
(3.2 \%)\end{array}$ & \\
\hline \multicolumn{7}{|c|}{ Health insurance is not worth cost } & $<0.001$ \\
\hline Disagreed & $\begin{array}{c}1848 \\
(38.1 \%)\end{array}$ & $\begin{array}{c}19252698 \\
(47.8 \%)\end{array}$ & $\begin{array}{c}556 \\
(28.7 \%)\end{array}$ & $\begin{array}{c}4601602 \\
(36.7 \%)\end{array}$ & $\begin{array}{c}1292 \\
(44.4 \%)\end{array}$ & $\begin{array}{c}14650000 \\
(52.9 \%)\end{array}$ & \\
\hline Uncertain & $\begin{array}{c}697 \\
(14.4 \%)\end{array}$ & $\begin{array}{c}6780511 \\
(16.9 \%)\end{array}$ & $\begin{array}{c}336 \\
(17.3 \%)\end{array}$ & $\begin{array}{c}2445884 \\
(19.5 \%)\end{array}$ & $\begin{array}{c}361 \\
(12.4 \%)\end{array}$ & $\begin{array}{c}4334626 \\
(15.6 \%)\end{array}$ & \\
\hline Agreed & $\begin{array}{c}1209 \\
(24.9 \%)\end{array}$ & $\begin{array}{c}12595583 \\
(31.3 \%)\end{array}$ & $\begin{array}{c}541 \\
(27.9 \%)\end{array}$ & $\begin{array}{c}4852302 \\
(38.7 \%)\end{array}$ & $\begin{array}{c}668 \\
(23.0 \%)\end{array}$ & $\begin{array}{c}7743281 \\
(27.9 \%)\end{array}$ & \\
\hline Missing & $\begin{array}{c}1094 \\
(22.6 \%)\end{array}$ & $\begin{array}{c}1621266 \\
(4.0 \%)\end{array}$ & $\begin{array}{c}505 \\
(26.1 \%)\end{array}$ & $\begin{array}{c}633618 \\
(5.1 \%)\end{array}$ & $\begin{array}{c}589 \\
(20.2 \%)\end{array}$ & $\begin{array}{c}987648 \\
(3.6 \%)\end{array}$ & \\
\hline \multicolumn{7}{|l|}{ More likely to take risks } & $<0.001$ \\
\hline Disagreed & $\begin{array}{c}2148 \\
(44.3 \%)\end{array}$ & $\begin{array}{c}22369348 \\
(55.6 \%)\end{array}$ & $\begin{array}{c}743 \\
(38.3 \%)\end{array}$ & $\begin{array}{c}6272301 \\
(50.0 \%)\end{array}$ & $\begin{array}{c}1405 \\
(48.3 \%)\end{array}$ & $\begin{array}{c}16100000 \\
(58.1 \%)\end{array}$ & \\
\hline Uncertain & $\begin{array}{c}701 \\
(14.5 \%)\end{array}$ & $\begin{array}{c}6687322 \\
(16.6 \%)\end{array}$ & $\begin{array}{c}292 \\
(15.1 \%)\end{array}$ & $\begin{array}{c}2122513 \\
(16.9 \%)\end{array}$ & $\begin{array}{c}409 \\
(14.1 \%)\end{array}$ & $\begin{array}{c}4564809 \\
(16.5 \%)\end{array}$ & \\
\hline Agreed & $\begin{array}{c}907 \\
(18.7 \%)\end{array}$ & $\begin{array}{c}9594789 \\
(23.8 \%)\end{array}$ & $\begin{array}{c}398 \\
(20.5 \%)\end{array}$ & $\begin{array}{c}3479823 \\
(27.8 \%)\end{array}$ & $\begin{array}{c}509 \\
(17.5 \%)\end{array}$ & $\begin{array}{c}6114966 \\
(22.1 \%)\end{array}$ & \\
\hline Missing & $\begin{array}{c}1092 \\
(22.5 \%)\end{array}$ & $\begin{array}{c}1598599 \\
(4.0 \%)\end{array}$ & $\begin{array}{c}505 \\
(26.1 \%)\end{array}$ & $\begin{array}{c}658770 \\
(5.3 \%)\end{array}$ & $\begin{array}{c}587 \\
(20.2 \%)\end{array}$ & $\begin{array}{c}939829 \\
(3.4 \%)\end{array}$ & \\
\hline
\end{tabular}

Note. The percentages represent the proportion of indicated responses in each item. They were weighted using SAQ weight variable. Missing data include responses coded as don't know, inapplicable, not ascertained. "Disagreed" includes strongly disagree and somewhat disagree. "Agreed" includes strongly agree and somewhat agree. 
Table 3. Odds ratios from logit models $(n=3,666)$

\begin{tabular}{|c|c|c|c|}
\hline Variables & OR & $95 \% \mathrm{Cl}$ & p-value \\
\hline \multicolumn{4}{|l|}{ Perceptions about health insurance } \\
\hline Do not need health insurance & 1.18 & $1.10-1.26$ & $<0.001$ \\
\hline Health insurance not worth cost & 1.11 & $1.04-1.18$ & 0.001 \\
\hline More likely take risks & 1.00 & 0.94-1.07 & 0.993 \\
\hline \multicolumn{4}{|l|}{ Demographics } \\
\hline \multicolumn{4}{|l|}{ Age } \\
\hline $18-24$ & - & - & - \\
\hline $25-44$ & 2.07 & $1.67-2.57$ & $<0.001$ \\
\hline $45-64$ & 1.79 & $1.41-2.27$ & $<0.001$ \\
\hline \multicolumn{4}{|l|}{ Gender } \\
\hline Male & - & - & - \\
\hline Female & 0.80 & $0.68-0.93$ & 0.005 \\
\hline \multicolumn{4}{|l|}{ Ethnicity } \\
\hline Hispanic & 2.53 & $2.15-2.98$ & $<0.001$ \\
\hline Non-hispanic & - & - & - \\
\hline \multicolumn{4}{|l|}{ Employment status } \\
\hline Employed & 1.42 & $1.21-1.67$ & $<0.001$ \\
\hline Unemployed & - & - & - \\
\hline \multicolumn{4}{|l|}{ Education } \\
\hline High school or less & 1.88 & $1.60-2.21$ & $<0.001$ \\
\hline Beyond high school & - & - & - \\
\hline \multicolumn{4}{|l|}{ Income } \\
\hline$\$ 1-\$ 22,200$ & 1.94 & $1.33-2.83$ & $<0.001$ \\
\hline$\$ 22,201-\$ 44,724$ & 1.92 & $1.48-2.48$ & $<0.001$ \\
\hline$\$ 44,725-\$ 82,006$ & 1.06 & $0.82-1.37$ & 0.643 \\
\hline$\$ 82,007$ or more & - & - & - \\
\hline \multicolumn{4}{|l|}{ Region } \\
\hline Northeast & - & - & - \\
\hline Midwest & 1.28 & $0.94-1.73$ & 0.118 \\
\hline South & 1.50 & $1.15-1.94$ & 0.002 \\
\hline West & 1.26 & $0.96-1.67$ & 0.094 \\
\hline \multicolumn{4}{|l|}{ Health status and utilization } \\
\hline Self-reported health status & 0.84 & $0.77-0.91$ & $<0.001$ \\
\hline \multicolumn{4}{|c|}{ Provider visit within the past 12 months } \\
\hline Never visited & 2.51 & $2.08-3.03$ & $<0.001$ \\
\hline Visited at least once & - & - & - \\
\hline \multicolumn{4}{|c|}{$\begin{array}{l}\text { Prescription drug refill within the past } 12 \\
\text { months }\end{array}$} \\
\hline Never refilled & 1.59 & $1.30-1.94$ & $<0.001$ \\
\hline Refilled at least once & - & - & - \\
\hline
\end{tabular}

Note. The categories without values represent references for each variable. Higher number in variables representing perceptions about health insruance indicates agreement to the statements and higher number of self-reported health status indicates excellent health status. 